\title{
Digitalizing the Municipality and Factors Affecting the Acceptance of E-municipality: An Empirical Analysis
}

\author{
İkram Daştan ${ }^{1}$ \\ ${ }^{1}$ Faculty of Economics and Administrative Sciences, Yalova University, Turkey \\ Correspondence: İkram Daştan, Faculty of Economics and Administrative Sciences, Yalova University, Turkey. \\ Tel: 90-226-815-51-45. E-mail: ikram.dastan@yalova.edu.tr
}

Received: November 3, 2015

Accepted: November 20, 2015

Online Published: November 25, 2015

doi: 10.5539/ibr.v8n12p104

URL: http://dx.doi.org/10.5539/ibr.v8n12p104

\begin{abstract}
Over the years, rapid developments in information and communications technologies have brought about an increase in the amount of time users spend online. Users who consistently interact online also resort to receiving goods and services that are supplied via these networks. This type of user behavior has also expedited the supply of services delivered by municipalities. In this regard, the purpose of the current study is to determine the factors affecting the adaptation of e-municipality services and their extent, by exclusively observing the leading e-municipality service provider. In order to achieve the purpose of the study, field research was conducted among 302 participants in the city of Yalova using the convenience-sampling technique.

The findings indicate that competence in the use of technology, perceived ease of use, perceived awareness and information quality positively influence the acceptance of e-municipality services whereas factors such as perceived trust and usability of resources have no significant impact.
\end{abstract}

Keywords: e-municipality, e-government, e-municipality acceptance, e-services

\section{Introduction}

Public administration is a discipline that has managed to comply with ongoing changes and continuous renovation at all stages during the globalization process. Parallel to these changes, employing new technologies and channels that rely upon such technologies as well as concepts such as e-administration, e-municipality, e-local administration and e-government in the field of public administration, the key objective of which is to provide services to meet public demands and elevate efficiency, began to be more frequently emphasized. Researchers from various disciplines continued to examine e-state concepts and theories with different points of view as a developing field. (Heeks, 2005; Joseph, 2013; Snead \& Wright, 2014). For local administrations, presentation of local services in the electronic environment means interacting with state institutions and organizations, private sector establishments and citizens via information technologies. Within municipality activities where personal satisfaction heavily depends on the quality of the services offered, the information flow, interaction and synchronous work among private sector establishments, individuals and local administration units can be executed in a more efficient manner with the assistance of information technologies.

From the specific aspect of public services in this modern age that witnesses the effective use of digital technologies and technology-use tendencies, the service demands and expectations of individuals also tend to change in an unpredictably quick way. In line with that change, local administrations are also expected to form a structure that can, at all times, meet unforeseen demands and expectations. In the formation of these structures one of the basic arguments is managing to achieve savings in several ways through easy and quick access to services. In this research, the objective is to identify the factors that might be effective in the social acceptance of municipality services presented in the electronic environment. Despite the extensive quantities of relevant studies in the literature, this research is distinguished from the rest by virtue of being a municipality-specific study that could be a torchbearer in the digitalization of services in particular and processes in general. Having laid the foundation for e-transformation in 1998, the Yalova Municipality has managed to transfer a number of its services to the electronic environment through digitalized work processes and by effectively utilizing business intelligence practices and reports it has developed technology-focused administration models. In one of these models some municipality employees can connect to the online-distance system via a flexible working model so as to execute their municipality tasks. This application is among the earliest of the public-related online practices 
in Turkey. From this viewpoint, in a municipality where digital technologies and promotion activities are efficiently used, the citizens' access and use of the services and the factors that played a role in the acceptance and popularization of services offered in electronic environments take the stage as noteworthy issues to consider. In an extensive body of studies in the relevant literature, the factors that played a role in the acceptance of e-services have already been analyzed. According to research findings, the primary factors were perceived awareness, usability of resources, computer self-efficacy, perceived usability, multi-language option, perceived information quality, perceived trust, perceived functional benefit and perceived image (Shareef, V. Kumar, U. Kumar, \& Dwivedi, 2011). In the present paper, among all these factors, technology-use competency, the trust factor, personal awareness and perceived information quality's effects on the acceptance of e-municipality were explored.

The main aim of this research is to determine the most common factors that are effective in the adaptation of citizens to e-municipality applications that are indicators of public service conversion specific to municipalities in Turkey. The unique value of the research and its contribution to the literature consists of the fact that the parties receive and provide services in a municipality where a homeworking (flexible) working system is being applied for the first time. In the first part of the research, e-state and e-municipality are defined and a municipality where the services and processes are digitalized is mentioned. In the second part of research, the e-municipality acceptance and the factors used in the research are evaluated, and the research model and hypotheses are formed. In the final part of the research, the formed model is tested using structural equation modeling and conclusions and suggestions take place.

\section{Digitalizing the Municipality}

According to Heeks and Bailur (2007), the era of the e-state phase dates back to 1997. There is no clear consensus about the concept or definition of e-government; however, there are some common elements between definitions (Holden, Norris, \& Fletcher, 2003; Halchin, 2004). In general terms, electronic government is the use of information and communication technologies in government settings (Gil-García, 2005). In other words, e-state is an information system that allows public management to be fulfilled using information and communication technologies. (Tung \& Rieck, 2005). E-state is defined briefly as "usage of IT services in services provided by the state" (Carter \& Belanger, 2005). E-municipality, as the local reflection of e-government services, is described as generating useful information for the city and society from such data and presenting to people the services in an efficient way by controlling city-related data via information technology-supported work based on modern technology (Henden, 2004). In another definition e-municipality services are noted as providing workflows and communication through electronic environments (Akınc1, 2004). In the literature, research related to e-state/municipality adaptation varies as the adaptation of organizations or citizens in developed and developing countries and the factors positively or negatively affecting the e-state adaptation are examined. (Tung \& Rieck, 2005; Lean, Zailani, Ramayah, \& Fernando, 2009; Shareef et al., 2011; Al-zoubi, Sam, \& Eam, 2011, Rokhman, 2011; Elbahnasawy, 2014). In research related to e-state adaptation (Carter \& Weerakkody, 2008; Warkentin, Pavlou, \& Rose, 2002; Carter \& Belanger, 2005), the preferable models and theories are generally the technology acceptance model (Davis, 1989), the innovation expansion theory (Rogers, 2003) and combined technology acceptance and usage theory (Venkatesh, Morris, Davis, \& Davis, 2003; Carter \& Weerakkody, 2008). In one of the studies performed using these models Carter (2008) states in the research aiming to determine the most effective adaptation factors that Perceived benefit, Perceived trust, usage of previous e-state services and Perceived ability to use variables significantly affect the tendency to use e-state services. In another study conducted in Canada, Perceived awareness, Availability of resources, Computer-self efficacy, Perceived compatibility, Perceived image, Perceived ability to use, Perceived information quality, Multilingual option, Perceived functional benefit, and Perceived trust were mentioned as critical factors affecting e-state adaptation. (Shareef et al., 2011). In the research that he conducted among 751 internet users in Indonesia, Rokhman (2011) stated that advantage, compatibility, ease of usage and image variables are effective in forecasting the e-state service usage tendencies of citizens. Generally, the research is focused on e-state adaptation and there are not many studies related to e-municipalities that are local reflections of e-state.

Electronic municipality (e-municipality) that should be viewed as a vital component of electronic government (e-government) is a project of wide scope that can accelerate municipalities' contribution to national development and welfare in almost all aspects (service, administration approach, new employment opportunities etc.). Within the framework of this project, via digitalized services transferred to the electronic environment, the aim is elevating the quality-service offer and local democracy by establishing interactive communication and information exchange between the municipality and local society. In order for municipalities to accomplish their 
inherent mission of providing services to the local community, they are required to transfer technological developments to organizational functioning (Y1ldırım \& Öner, 2004).

Financial, social, and cultural transformations in society and technological developments have shifted the relationship between the rulers and the ruled from a one-way, passive relationship to a bidirectional active relationship that motivates continuous interaction. This new situation has extensively transformed the local administration approach and local service benchmarks that are the determinants of this approach (Şat, 2012).

On the basis of the definitions above, the earliest actions towards e-transformation of Yalova Municipality-constituting the scope of present research-started in 1998. In the realization of Turkey's aim to adapt the e-Europe action plan, Yalova was selected by the Prime Ministry as the pilot region for local administration in the e-Turkey project. Within the body of the Municipality, the (ZAMBAK) project was started in 2012. With this project Internet-based management information system applications were integrated with total-quality management applications by following process logic; hence an authentic public administration application model independent of time and place was devised. Within the scope of this Project, definition of all the tasks in the municipality services in terms of duration and responsible names, coordination of all work processes in the interactive environment and continuous improvement formed the key elements of the model. The flow process of all appeals, complaints, documents and tasks executed within the body of the Municipality was defined by the electronic-document-management system. In sum, approximately 4,000 processes, 359 different appeal forms and 164 different complaint forms were defined and in this way it became feasible to establish at what stage the tasks would be transferred to relevant personnel. Service desk personnel initiate the work flow by identifying the applicable work flow definition for the incoming appeal. From this very first trigger until completion of the work, the stages in between are executed in order in the electronic environment (Zambak, 2012). Personnel can sign the document with an electronic signature, thus information integrity, identity authentication and verification, and incontestability can be assured. With the assistance of information and communication technologies, services could be distance-accessible and virtualized. In a study conducted within the institution it was detected that in 2012 it offered around one million in revenue to the institution (İnan, 2014). In another stage of the Project it was aimed that employees would be flexible. Or put differently, they would be independent of time and space and employees would perform their work by connecting to the system from home. When the system was first launched in 2010 the number of distance (flexible) working employee was 163, whereas in 2014 this figure climbed to 350 and $70 \%$ of employees were then able to work at a distance (İnan, 2014a). Also within the scope of Project, the entire sets of documents incoming to the municipality and generated within the municipality were transferred to the digital environment and stored in digital archives. None of the documents were physically transferred and signatures were put in the electronic environment. Throughout the years a visible increment has been observed in the number of services and virtualization ratio. In 2008 there existed 38,300 services in sum and virtualization was measured as 30\% whilst in 2013 the number of services climbed to 76,517 and virtualization ratio climbed to $45 \%$ (İnan, 2014).

With the launch of digitalized work flow within the body of the Municipality, time-consuming and demanding work could be completed in much shorter periods. For instance, business intelligence reports clearly evidenced that periods of zoning status appeal fell from one month to one day. By the same token, appeals for building permits were lowered to two hours and the occupancy permit process was lowered from one month to four days (İnan, 2014).

Within the specific context of Yalova Municipality, the transfer of services to the electronic environment, as widely reported in literature, is most effectively executed in an environment that offers digital services in which citizens can receive services independent of time and space by connecting to the system and public employees can provide service anytime anywhere by connecting to the system. In other words, in such an environment where both parties are mobile the factors affecting e-municipality acceptance and the direction of these effects are the highlighted issues that demand in-depth analysis.

\section{E-municipality Acceptance and Conceptual Framework}

Unlike other public authorities, as one of the major service providers municipalities are defined as institutions that are in tight connection with the public and in close interaction with the local citizens. The reason for this close relationship is that municipalities' responsibilities are intricately intertwined with the daily life of the community (Nadaroğlu, 1994). Before the presentation of services in electronic environments individuals used to visit the municipal offices in person to submit their appeals physically. Once the way services were provided changed format, certain individuals still chose to access municipal services by resorting to the traditional method, whereas some started to make use of the services presented in electronic environments. In the acceptance of 
e-municipality where the technology-affiliation of individuals plays the most dominant role, other effective factors were analyzed by a large number of scholars and the effect level and direction on e-municipality acceptance were examined.

Local administration e-government services outrivaled central administration e-government services and also model cases from other countries outperformed in terms of service maturity. In a large number of different surveys, more than $20 \%$ of individuals not utilizing e-government services reported that the reason they failed to use this service was their lack of knowledge of the availability of e-government services. Lack of awareness of e-municipality services negatively affected the e-municipality service use levels of people (Ministry of Development, 2013). Within the scope of the information society strategy renewal project executed by the Ministry of Development in 2013, the e-government services usage questionnaire was directed to users and they were asked to list the government and municipality e-government services they most frequently utilized. Next, awareness of the electronic environment of these services was researched. Of the participants with Internet access, 26\% reported most frequently using central administration e-government services and 34\% reported most frequently using municipality e-government services (Ministry of Development, 2013). Lack of awareness among individuals has been confirmed in other studies as well. In the e-government/e-municipality user satisfaction survey featured by TÜSİAD and the Turkish Foundation for Information in 2011, it was revealed that the reason explaining the failure of $26 \%$ of Turkish people to use e-government service was lack of awareness. It is thus safe to argue that one great challenge against the increase in e-government/e-municipality services is the low level of awareness towards this issue (Ministry of Development, 2014). Failure of individuals to recognize services offered can affect the demand towards these services. Rehman, Esichaikul and Kamal (2012), in their co-work detected that awareness is a crucial factor that affects the tendency of people to use e-government services. In another study, Shareef et al., (2011) argued that a positive correlation existed between perceived awareness and e-government adaptation. In view of this perspective, $\mathrm{H} 1$, the first hypothesis of the present research, is as stated below.

H1: Perceived awareness positively affects e-municipality acceptance.

The trust concept has long been intensely studied by researchers from a range of disciplines. Each discipline interpreted the concept in line with its own field (Colesca, 2009). Trust is a major concept that connects humans and establishments and determines the continuity, strength and intensity of mutual relationships. Trust also relates to a statement of the expectations that an individual bears for the future depending on his/her previous interactions (Roca, García, \& de la Vega, 2009). Privacy and security of online services can be analyzed with respect to two dimensions (Yild1z, 2003). One dimension is that while administration units offer services to individuals and institutions it is feasible that some confidential information could be hacked by sinister third parties. The other dimension is that certain public information of a confidential nature could potentially turn into a national security threat. On account of these reasons and others, information in the system must be stored in a secure space and while presenting e-government services privacy principles must followed decisively by all individuals (Demirel, 2006).

Presenting services in electronic environments assigns both parties significant duties. Since state-provided electronic services are not offered on alternative websites, citizens with unsettled trust issues towards e-government websites resort to traditional service methods since there are no other website options available (Teo, Srivastava \& Jiang, 2008). Additionally, individuals can utilize various platforms and applications to access e-government services. Trust towards such assorted tools and platforms is also largely responsible for e-government acceptance (Daştan, \& Geçti, 2014). Concerning this issue a list of researchers reported that trust is a dimension critically effective in e-government acceptance. In a study conducted by Warkentin et al. (2002), an investigation was conducted between built-trust and e-government acceptance and they reported that citizens' trust is a major determinant of e-government acceptance. Carter and Belanger (2005) in their England-based research among 105 individuals revealed the relationship between trust and e-government acceptance. By the same token Wu and Chen (2005), in Taiwan-based research among 1,032 participants, analyzed the relations of trust with other factors effective on e-government acceptance. They put forth that there are interconnected relations between trust and listless factors that affect e-government acceptance. Some researchers, however, examined the relation between e-government acceptance and trust, but failed to spot any findings evidencing the interconnection between the two (Morgeson, Forrest, Van Amburd, \& Mithas, 2011). West (2004) in his research covering visitors to e-government websites concluded that there existed no significant relationship between e-government websites and trust. The second hypothesis of the present research was structured on the dimension of trust as below.

H2: Perceived trust positively affects e-municipality acceptance. 
The quality level of the information people can access in the electronic environment attracts attention as a critical issue. Perceived information quality refers to users' trust towards features such as context, format, accuracy and actuality that electronic environments possess (Rai, Lang, \& Welker, 2002). Accuracy, actuality and easy-intelligibility of information and easy access to all kinds of information that can meet personal needs transpose into information quality that in effect transforms this element into a critical factor. In addition, presenting the services in electronic environments in an orderly and systematic fashion, offering additional information to users and continuously updating the information are vital factors for system functioning as well as acceptance of e-municipality systems among people. In a study conducted to identify the critical factors affecting the e-government service adaptation of individuals, it was detected that the information quality level was effective on state adaptation and information quality emerged as a major variable in collecting data from an official website (Rehman et al., 2012). Shareef et al. (2011) in their work detected that perceived information quality is one of the critical factors affecting e-government adaptation. In a different study it was identified that perceived information quality navigated ease of use that in effect positively affected users' attitudes (A. Türker \& Ö. Türker, 2013). Palmer (2002), in his research, manifested that high level of information quality is positively correlated with the success of a website. As a result, the third hypothesis of this research is as stated below.

H3: Information quality positively affects e-municipality acceptance.

As a grand component in social psychology, self-efficacy refers to personal skills that any individual bears in accomplishing certain tasks (Bandura, Adams, \& Beyer, 1977). Computer self-efficacy specifically relates to personal competency in computer usage (Compeau, 1995). Human competency towards using information and communication technologies has been defined and exemplified in a wide array of studies. Most of these studies put forth that computer self-efficacy and usage behaviors are interrelated (Burkhardt \& Brass, 1990; Webster \& Martocchio, 1993). The same condition was also exemplified with factors such as Technical Skill, Computer Usage Proficiency, and Technology Usage Skill and has occasionally been described as using the system under perceived behavioral control and the perception on the existence of essential skills, means and resources. This concept, which is basically termed as human skills in the use of the computer, the Internet and relevant technologies has a direct effect on user operations in online environments. When viewed as a whole unity this concept is also inextricably connected with the digital dividend. Even though there are abundant technology investments of private firms, state institutions and organizations this welfare does not necessarily translate into better adoption and higher frequency of use of technology. In this paper, the last hypothesis relates to the factor termed as technology-use competency.

H4: Technology use competency positively affects e-municipality acceptance.

Perceived ease-of-use constitutes the section in which individuals evaluate the usability of a system. The ease and practicality of navigating the system and ease of performance of operations are the main components of this factor. Constituting the scope of much research in the literature, perceived ease-of-use is described as the intensity of mental and physical effort that an individual envisages using during the state of technology use. Put differently, it is defined as the level of effort involved when using a specific class of technology (Davis, 1989). Sang, \& Lee, J. (2010), in their work, identified that via perceived benefit, perceived ease-of-use renders an indirect effect on e-government adaptation. In another study Rehman et al. (2012), manifested that perceived ease-of-use is a vital factor that affects citizens' tendencies to perform state-relevant procedures. Rokhman (2001) in his study covering 751 Internet users, verified that ease-of-use is a predictor in citizens' tendencies to use e-government services. Carter (2008) conducted a study to reveal the most powerful adaptation factors and concluded that perceived benefit, trust towards the Internet, use of previous e-government services, and perceived ease-of-use are the variables that exponentially affect the tendency to use any e-government service. As the next hypothesis of this research the kind of effect that perceived ease-of-use has on e-municipality acceptance will be sought.

H5: Perceived ease-of-use positively affects e-municipality acceptance.

The factor of use of resources that is termed as the lack of adequate resources for users to access the service is one of the most dominant factors affecting the acceptance of services presented in electronic environments. Lack of information and knowledge of communication technologies or failure to access these technologies can also directly affect adaptation. The scholars who defined inaccessibility to computer and Internet technologies among different people coined the terms digital inequality or digital segregation and the same scholars argued that once this greatest barrier against the spread of technology is lifted it then becomes feasible to offer widespread e-government applications (Şişman, Alkış, \& Maraş, 2011). Other researchers also investigated the usability of resources. One researcher, Norris (1984), discovered the relationship between usability of resources and 
adaptation. In more research, Shareef et al. (2011), claimed that usability of resources is among the most critical factors affecting e-government adaptation. Accordingly the last hypothesis of this research is as stated below.

H6: Usability of resources positively affects e-municipality acceptance.

The model created to test research hypothesis is displayed in Figure 1.

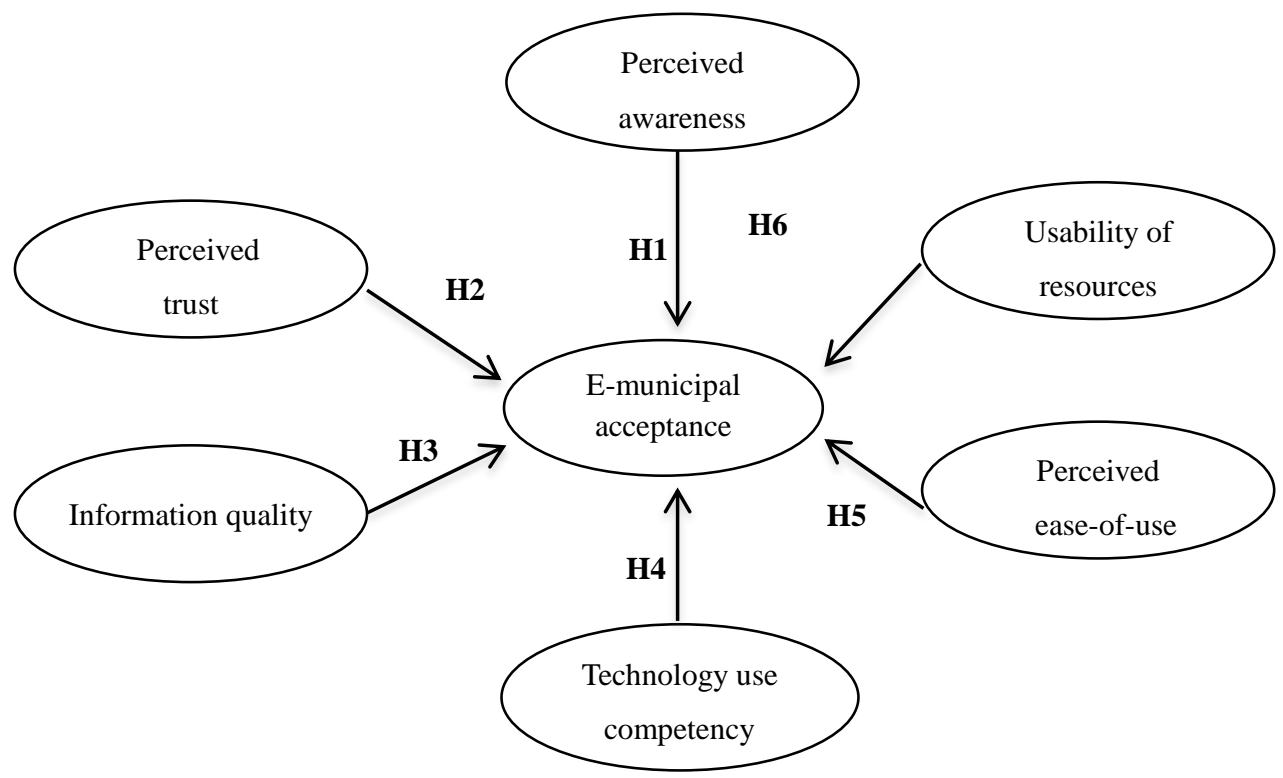

Figure 1. Proposed model

\section{Method}

\subsection{Research Objective}

The preliminary objective of this research was to determine the direction of the effects of factors listed as perceived ease-of-use, technology-use competency, trust, usability of resources, personal awareness and information quality on e-municipality acceptance.

\subsection{Sampling and Data Collection}

Within the scope of this research covering the Yalova region, the initial attempt was to reach 500 individuals via the convenience sampling method. With the exclusion of missing and incomplete questionnaires the research was applied to a total of 302 individuals. The scales used in the research were adapted from Shareef et al. (2011) and Kumar et al. (2007). The survey form used in the research consisted of two sections.

In the first part of the questionnaire demographic factors, computer and Internet use ratios, and most-frequently visited e-municipality services were intended to be identified via relevant statements. In the second part a section composed of factor groups with 35 statements in sum was created.

Of all 302 participants, 147 were male (48.7\%), and 155 were female $(51.3 \%) .8 .3 \%$ of individuals had income levels below $\$ 500,16.9 \%$ had income levels between $\$ 501-750,32.5 \%$ had income levels between $\$ 751-1,250$, $29.8 \%$ had income levels between $\$ 1,251-1,750,10.3 \%$ had income levels between $\$ 1,751-2,500$, and 2.3\% had income levels above $\$ 2,500.2 \%$ of participants were elementary school graduates, $3 \%$ were secondary school graduates, $35.8 \%$ were high school graduates, $48 \%$ were college graduates, and $11.2 \%$ had post graduate degrees.

\subsection{Data Analysis}

Prior to applying structural equation modeling, the measurement model was tested with the two-stage approach model of Anderson and Gerbing (1988). Firstly, the confirmatory factor analysis was conducted to test the validity and reliability of the measurement model. Then, the research hypotheses were tested for the structural model.

The measurement model included thirty five observed variables. These observed variables are explained by 
seven latent variables. The latent variables of the proposed model are respectively perceived awareness (PA), perceived trust (PT), information quality (IQ), technology-use competency (TUC), perceived ease-of-use (PEU), usability of resources (UR) and e-municipality acceptance (eMA). The measurement model (Figure. 1) was tested by employing the calculation of maximum-likelihood.

Test results indicated that $(\chi 2 / \mathrm{sd}-4.716$, RMSEA 0.111, NFI 0.760, CFI 0.800 , GFI 0.701, AGFI 0.645) there is unacceptable fit between measurement model and data.

Upon analyzing item factor loads, standard error covariance coefficients and modification indicators problematic items were identified. In the measurement model, variables PA3 and PA4 in perceived awareness (PA) factor were excluded due to their low factor loads; PT2 and PT3 variables in perceived trust (PT) factor; IQ1, IQ2, IQ4, IQ5, IQ8 in information quality (IQ) factor; TUC3 and TUC4 in technology use competency (TUC) factor; PEU2 and PEU5 in perceived ease-of-use (PEU) factor; UR2 in usability of resources (UR) factor and finally eMA1 variable in e-municipality acceptance (eMA) factor were excluded since their low and insignificant ( $>0.05)$ factor loads were highly correlated with the error terms of the problems in remaining variables. However, between error terms of items PEU1 and PEU4, which were deemed to be effective in the formation of each other, the emerging correlation was permitted. Upon excluding these statements, the measurement model was finalized in format and confirmatory analysis was repeated.

The fit indices $(\mathrm{CMIN} / \mathrm{df}=2.432 \mathrm{GFI}=0.91, \mathrm{NFI}=0.93, \mathrm{CFI}=0.96, \mathrm{RMSEA}=0.69)$ indicated that there was acceptable fit between the data and the model. Goodness of fit values for item factor loads and measurement model are shown in Table 1.

Table 1. Measurement items \& reliability

\begin{tabular}{lccc}
\hline \multicolumn{1}{c}{ Construct } & $\begin{array}{c}\text { Average Variance } \\
\text { Extracted (AVE) }\end{array}$ & Cronbach Alfa & $\begin{array}{c}\text { Composite } \\
\text { Reliability (CR) }\end{array}$ \\
\hline Perceived ease-of-use & 0.73 & 0.862 & 0.89 \\
Technology use competency & 0.95 & 0.976 & 0.97 \\
Perceived trust & 0.62 & 0.835 & 0.82 \\
Usability of resources & 0.65 & 0.839 & 0.84 \\
Perceived awareness & 0.70 & 0.815 & 0.82 \\
Information quality & 0.63 & 0.839 & 0.84 \\
E-municipality acceptance & 0.81 & 0.897 & 0.89 \\
\hline
\end{tabular}

It was revealed that composite reliability (C.R.) values were above 0.60 (Bagozzi \& Yi, 1988), which is threshold value for all variables. It was then identified that Cronbach alpha coefficients were also greater than the threshold value of 0.70, thus it was concluded that the scales were reliable (Berthon, Ewing, \& Hah, 2005).

Table 2. Item-factor loads

\begin{tabular}{lc}
\hline Factors and Scales & Factor Loads \\
\hline Perceived ease-of-use & 0.79 \\
PEU1 : It is easy to learn how to use e-municipality websites. & 0.88 \\
PEU3 : It is easy to surf in e-municipality websites. & 0.89 \\
PEU4 : Operations in e-municipality websites are clear and understandable. & 0.73 \\
Perceived trust & 0.78 \\
PT1 : e-municipality websites are really secure. & 0.84 \\
PT4 : Municipality assumes full responsibility against security threats that could emerge in website & \\
operations. & 0.98 \\
PT5 : Legal and technological policies of the website protects me against internet-based problems. & 0.97 \\
Technology use competency & 0.83 \\
TUC1 : I have computer use competency. & 0.87 \\
TUC2: I have internet-use competency. & \\
Usability of resources & \\
UR1 : I have sufficient computer technology at home. & \\
UR3 : I have continuous Internet connection at home. & \\
\hline
\end{tabular}


UR4 : I have continuous Internet connection at work.

\section{Perceived awareness}

PA1 : I am aware that Yalova Municipality has a website.

0.74

PA2 : I am aware of the benefits of using e-municipality websites.

0.93

Information quality

IQ3 : E-municipality websites provide me all kinds of information needed to meet my demands.

IQ6 : E-municipality websites openly present the principles of municipality on the functions of website.

IQ7 : E-municipality websites also provide additional information to its users.

As the factor loads of questions are examined it surfaces that all questions are loaded in a high and significant factor load to the factors to which they belonged; hence convergent validity was achieved. Besides, the fact that explained variance coefficient for all scales is above 0.50 is another indicator of achieving convergent validity (Fornell \& Lacker, 1981). To ensure that structures did not measure identical topics or opinions, or in other words for the sake of detecting if each structure in the measurement model provided discriminant validity, the structures were matched in groups of two and validity was predicted (Joreskog, 1993). To illustrate; "perceived ease-of-use" structure was matched with "perceived use competency" structure and whether these two structures had discriminant validity was analyzed. Next, "perceived ease-of-use" and "usability of resources" structures were tested in the same way and the same operation was repeated for all potential dual matching groups.

For both restricted and unrestricted models $\chi^{2}$ and degree of freedom values were measured. Next $\chi^{2}$ differences test was conducted on two models. Unrestricted model values that visibly have lower $\chi^{2}$ values than the restricted model validated that discriminant validity was achieved (Anderson \& Gerbing, 1988; Bogazzi \& Phillips, 1982).

\subsection{Testing the Hypotheses}

Structural model created by latent variables to check the hypotheses of research was tested by utilizing the maximum-likelihood calculation technique. Goodness of fit indices indicated an acceptable fit $(\chi 2 / \mathrm{df}=2.342$, $\mathrm{GFI}=0.91, \mathrm{NFI}=0.93, \mathrm{CFI}=0.96, \mathrm{RMSEA}=0.06$ ). Upon conducting an overall analysis on the created model, the findings on the relationships promulgated in research hypotheses are as displayed in Table 3 . In the light of testing results, all hypotheses were accepted.

Table 3. Results of hypothesis test

\begin{tabular}{lcccc}
\hline \multicolumn{1}{c}{ Hypothesized Path } & Coefficient & T-Value & Sig. & Result \\
\hline H1: Perceived awareness $\Rightarrow$ E-municipality acceptance & .371 & 4.747 & $* * *$ & Supported \\
H2: Perceived security $\Rightarrow$ E-municipality acceptance & .043 & 0.315 & .753 & Rejected \\
H3: Information quality $\Rightarrow$ E-municipality acceptance & .743 & 3.294 & $* * *$ & Supported \\
H4: Technology use competency $\Rightarrow$ E-municipality acceptance & .251 & 3.447 & $* * *$ & Supported \\
H5: Perceived ease-of-use $\Rightarrow$ E-municipality acceptance & .297 & 1.963 & .050 & Supported \\
H6: Usability of resources $\Rightarrow$ E-municipality acceptance & .063 & 0.776 & .443 & Rejected \\
$\mathrm{R}^{2}$ (E-municipality acceptance) $=.52$ & & & & \\
\hline
\end{tabular}

\section{Conclusion}

Various researchers have analyzed the factors that affect e-government acceptance from different aspects and contributed greatly to the relevant literature. The foundation of e-government/e-municipality services is related to the transfer of the services of digitalized state institutions and organizations to the electronic environment. At this point it surfaces that e-municipality acceptance is highly dependent on the extent a municipality can transfer its services to digital environments and form an effective structure. In this paper, a municipality in which almost the entire system was digitalized and even the employees were not required to come to work in-person but to complete their tasks by connecting to the virtual environment was examined and it was identified that several different factors played roles in e-municipality acceptance among individuals. 
Participants reported having used a computer (78.1\%) and the Internet $(71.2 \%)$ for a remarkably long period (10 years and above). $90.1 \%$ of participants reported connecting to the Internet on a daily basis.

Personal awareness on the availability of various services on the municipality website and potential benefits of using such services via these environments are, most of the time, directly effective factors on e-municipality acceptance. By the same token, promotional activities executed by municipalities would positively contribute to this process. During its digitalizing process, Yalova Municipality effectively continued its promotional activities in both national media and local organs. Within the scope of this research it was identified that perceived awareness of individuals positively contributed to e-municipality acceptance. In an array of studies in the relevant literature (Rehman et al., 2012, Shareef et al., 2011) similar findings were obtained. Once people develop awareness on the presentation of municipality services in the electronic environment and high level of benefit it provides, the ratio of using services via these environments correspondingly increases.

Users expect that websites from which they receive service assume full responsibility against any potential problems. Security level of the website, protection of personal information, problem-free communication, privacy of information, absence of any uncertainty, easy access to relevant personnel on the emergence of a problem and quick solution-generation and several other factors boost the perceived security level. An individual who can complete his/her procedures quickly and smoothly feels satisfied and tracks the same path in future purchases of services. On the other hand, an individual who faces a negative experience on an e-government website may, in future purchases of services, choose to purchase service in physical environments. Nonetheless, the obtained findings indicated that perceived security factor had no effect on e-municipality acceptance. This finding is identical to a number of studies in the relevant literature (Morgeson et al., 2011, West, 2004). This finding stems from the fact that the system was well-promoted by the municipality, individuals trusted the system and users experienced no problem while interacting with e-services.

Offering accurate, reliable, actual, understandable and additional information on services and offering re-direction to relevant sites where necessary are directly connected to the information quality in municipality websites. In this study, it was detected that information quality perceived by individuals created a positive effect in e-municipality acceptance. The same correlation is echoed in relevant-literature studies (Rehman et al., 2012, Shareef et al., 2011, Türker, A. \& Türker, Ö. 2013, Palmer, 2002). Consequently, it can be asserted that e-municipality acceptance becomes much easier when perceived information quality increases.

On a broad scale technology competency is a vital component for all organizations and systems. This component that relates to people's ability to use a computer, the Internet and miscellaneous technologies directly affects user operations in online environments. Insufficient knowledge of information and communication technologies directly affects e-municipality acceptance. In this study it was also identified that perceived technology-use competency positively affected e-municipality acceptance. In many studies in the literature (Burkhardt \& Brass, 1990; Webster \& Martocchio, 1993) researchers evidenced the above findings.

In relevant research, the perceived ease-of-use factor has been one of the first analyzed factors in studying adaptation. Ease-of-use of the services presented in electronic environments has been one of the dominant factors that affected e-municipality acceptance for individuals from all groups. A person who experienced a negative process in the use of an e-municipality website could, in future service purchases, resort to physical environments. In accordance with this manifestation and research findings it was detected that perceived ease-of-use has a positive effect on e-municipality acceptance. In the relevant literature, several other scholars (Rokhman, 2001, Carter, 2008, Sang et al., 2010, Rehman et al., 2012) obtained similar results as well.

Absence of knowledge of information and communication technologies is likely to directly affect access to the services offered in the electronic environment. In different studies (Norris, 1984, Shareef et al., 2011) it was manifested that this condition-also termed 'usability of resources'-positively affected e-government adaptation. In our research, on the other hand, it was identified that the usability of resources factor had no effect on e-municipality acceptance. It then becomes feasible to claim that absence of information communication technologies does not necessary mean failure to use this technology. In any given environment, individuals can access these services and easily utilize the offered services. This condition has no effect on e-municipality acceptance. Services that municipalities create in various spots can be reached by users via online access points. In that way the effect of this structure is eliminated.

As a result, the most important factor in conducting municipality services in the electronic environment is the awareness of the services. The best method to raise this awareness is advertising and introduction activities. Efficiently conducting introduction activities, correct building and explanation of the system infrastructure and processing results creates reliance of users towards the system. From this point of view, it can be observed that 
the trust factor is not effective on adaptation.

On the other hand, the research findings suggest that the majority of municipality employees working from home constitute importance in terms of the processing of the services provided. For this reason the unique value of this study consists of presenting the extent of a variety of factors affecting adaptation of an e-municipality with such a structure. Another interesting result of the research is that source usage and trust are not effective in acceptance of significantly digitalized services and processes. On the other hand ease of usage, information quality, technology usage sufficiency and awareness have positive effects.

\section{Limitations of the Research and Future Studies}

Despite the existence of a vast scope of factors affecting e-municipality adaptation in the relevant literature, the effect of only six factors on acceptance was examined in this particular research. This is one of the limitations of this research. The second limitation of this research is that since it would be a challenge to reach the entire population, the convenience sampling method was selected. A sampling cannot possibly represent the entire population. Consequently, it is not feasible to generalize the results obtained from this research. The third limitation is that due to limited budget the research was confined to Yalova region and failed to encompass a wider territory. Subsequent to this research it would be wise to suggest such implications for future studies: In future, the entire list of factors affecting adaptation to the research model or most of the factors accepted in the relevant literature could be integrated. In addition, the effects of several mediator variables could also be analyzed within the scope of the model. The same research could be repeated in different regions.

This article is based on the paper presented at the YBS 2015 Congress.

\section{References}

Akinci, H. (2004). Geospatial web services for e-municipality. International Archives of Photogrammetry Remote Sensing and Spatial Information Sciences, 35(2), 1682-1750.

Al-Zoubi, M., Sam, T. L., \& Eam, L. H. (2011). E-government adoption among businesses in Jordan. Academic Research International, 1(1), 141-156.

Anderson, J. C., \& Gerbing, D. W. (1988). Structural equation modeling in practice: A review and recommended two-step approach. Psychological Bulletin, 103(3), 411. http://dx.doi.org/10.1037//0033-2909.103.3.411

Bagozzi, R. P., \& Phillips, L. W. (1982). Representing and testing organizational theories: A holistic construal. Administrative Science Quarterly, 459-489. http://dx.doi.org/10.2307/2392322

Bagozzi, R. P., \& Yi, Y. (1988). On the evaluation of structural equation models. Journal of the Academy of Marketing Science, 16(1), 74-94. http://dx.doi.org/10.1007/bf02723327

Bandura, A., Adams, N. E., \& Beyer, J. (1977). Cognitive processes mediating behavioral change. Journal of Personality and Social Psychology, 35(3), 125. http://dx.doi.org/10.1037//0022-3514.35.3.125

Berthon, P., Ewing, M., \& Hah, L. L. (2005). Captivating company: Dimensions of attractiveness in employer branding. International Journal of Advertising, 24(2), 151-172.

Burkhardt, M. E., \& Brass, D. J. (1990). Changing patterns or patterns of change: The effects of a change in technology on social network structure and power. Administrative Science Quarterly, 104-127. http://dx.doi.org/10.2307/2393552

Carter, L. (2008). E-government diffusion: A comparison of adoption constructs. Transforming Government: People, Process and Policy, 2(3), 147-161. http://dx.doi.org/10.1108/17506160810902167

Carter, L., \& Bélanger, F. (2005). The utilization of e-government services: Citizen trust, innovation and $\begin{array}{lllll}\text { acceptance factors. Information Systems } & \text { Journal, } & \text { 15(1), }\end{array}$ http://dx.doi.org/10.1111/j.1365-2575.2005.00183.x

Carter, L., \& Weerakkody, V. (2008). E-government adoption: A cultural comparison. Information Systems Frontiers, 10(4), 473-482. http://dx.doi.org/10.1007/s10796-008-9103-6

Colesca, S. E. (2009). Increasing e-trust: A solution to minimize risk in e-government adoption. Journal of Applied Quantitative Methods, 4(1), 31-44.

Compeau, D. R., \& Higgins, C. A. (1995). Computer self-efficacy: Development of a measure and initial test. MIS Quarterly, 189-211. http://dx.doi.org/10.2307/249688

Dastan, I., \& Gecti, F. (2014). Relationships among utilitarian and hedonic values, brand affect and brand trust in the smartphone industry. Journal of Management Research, 6(2), 124-139. 
http://dx.doi.org/10.5296/jmr.v6i2.5261

Davis, F. D. (1989). Perceived usefulness, perceived ease of use, and user acceptance of information technology. MIS Quarterly, 319-340. http://dx.doi.org/10.2307/249008

Demirel, D. (2006). E-devlet ve Dünya Örnekleri. Sayıştay Dergisi, 61(6), 83-118.

Elbahnasawy, N. G. (2014). E-government, internet adoption, and corruption: An empirical investigation. World Development, 57, 114-126. http://dx.doi.org/10.1016/j.worlddev.2013.12.005

Fornell, C., \& Larcker, D. F. (1981). Evaluating structural equation models with unobservable variables and measurement error. Journal of Marketing Research, 39-50. http://dx.doi.org/10.2307/3151312

Gil-Garcia, J. R. (2005). Enacting state websites: A mixed method study exploring e-government success in multi-organizational settings. In University at Albany, State University of New. http://dx.doi.org/10.1109/hicss.2006.149

Halchin, L. E. (2004). Electronic government: Government capability and terrorist resource. Government Information Quarterly, 21(4), 406-419. http://dx.doi.org/10.1016/j.giq.2004.08.002

Heeks, R. (2005). E-Government as a Carrier of Context. Journal of Public Policy, 25(1), 51-74.

Heeks, R., \& Bailur, S. (2007). Analyzing e-government research: Perspectives, philosophies, theories, methods, and practice. Government information quarterly, 24(2), 243-265. http://dx.doi.org/10.1016/j.giq.2006.06.005

Holden, S. H., Norris, D. F., \& Fletcher, P. D. (2003). Electronic government at the local level: Progress to date and future issues. Public Performance \& Management Review, 325-344.

Inan, Y. D. (2014, October). Bilgi Toplumunda Kamu Örgütlenme Modeli: Yalova Örneği. Paper presented at the First Conference on Management Information Systems, İstanbul, Turkey.

Inan, Y. D. (2014) Bilgi Ve Iletişim Teknolojilerinin Gelişimiyle Kamu Kurumlarinda Uzaktan Çalişmanin Uygulanabilirliği (Unpublish mastes's thesis). University of Yalova, Yalova, Turkey.

Jöreskog, K. G. (1993). Testing structural equation models. Sage Focus Editions, 154, 294-294.

Joseph, R. C. (2013). A structured analysis of e-government studies: Trends and opportunities. Government Information Quarterly, 30(4), 435-440. http://dx.doi.org/10.1016/j.giq.2013.05.006

Kalkınma, B. (2013) Bilgi Toplumu Stratejinin Yenilenmesi Projesi. Retrieved from www.bilgitoplumustratejisi.org/download/docfile/8a32476640e074570140e4b6ba8b0002+\&cd=2\&hl= $\operatorname{tr} \& \mathrm{ct}=\mathrm{clnk} \& \mathrm{gl}=\mathrm{tr}$

Kalkınma, B. (2014) 2015-2018 Bilgi Toplumu Strateji ve Eylem Plani. Retrieved from http://www.kalkinma.gov.tr/Lists/Duyuru\%20ve\%20Haberler/Attachments/681/20152018_bilgi_toplumu_s tratejisi_ve_eylem_plani.pdf

Kumar, V., Mukerji, B., Butt, I., \& Persaud, A. (2007). Factors for successful e-government adoption: A conceptual framework. The Electronic Journal of E-government, 5(1), 63-76.

Lean, O. K., Zailani, S., Ramayah, T., \& Fernando, Y. (2009). Factors influencing intention to use e-government services among citizens in Malaysia. International Journal of Information Management, 29(6), 458-475. http://dx.doi.org/10.1016/j.ijinfomgt.2009.03.012

Morgeson, F. V., VanAmburg, D., \& Mithas, S. (2010). Misplaced trust? Exploring the structure of the e-government-citizen trust relationship. Journal of Public Administration Research and Theory, muq006. http://dx.doi.org/10.1093/jopart/muq006

Nadaroğlu, H. (1994). Mahalli İdareler Teorisi-Ekonomisi-Uygulaması, 5. Bask1, Beta Yayınc1lı, İstanbul.

Norris, D. F. (1984). Computers and small local governments: Uses and users. Public Administration Review, 70-78. http://dx.doi.org/10.2307/975666

Palmer, J. W. (2002). Web site usability, design, and performance metrics. Information systems research, 13(2), 151-167. http://dx.doi.org/10.1287/isre.13.2.151.88

Rai, A., Lang, S. S., \& Welker, R. B. (2002). Assessing the validity of IS success models: An empirical test and theoretical analysis. Information systems research, 13(1), 50-69. http://dx.doi.org/10.1287/isre.13.1.50.96

Rehman, M., Esichaikul, V., \& Kamal, M. (2012). Factors influencing e-government adoption in Pakistan. Transforming Government: People, Process and Policy, 6(3), 258-282. http://dx.doi.org/10.1108/17506161211251263 
Carlos, R. J., José, G. J., \& José, V. J. (2009). The importance of perceived trust, security and privacy in online trading systems. Information Management \& Computer Security, 17(2), 96-113. http://dx.doi.org/10.1108/09685220910963983

Rogers, E. (2003). Diffusion of Innovations. New York: Free Press.

Rokhman, A. (2011). E-government Adoption In Developing Countries: The Case of Indonesia. Journal of Emerging Trends in Computing and Information Sciences, 2(5), 228.

Sang, S., Lee, J. D., \& Lee, J. (2010). E-government adoption in Cambodia: A partial least squares approach. Transforming Government: People, Process and Policy, 4(2), 138-157. http://dx.doi.org/10.1108/17506161011047370

Shareef, M. A., Kumar, V., Kumar, U., \& Dwivedi, Y. K. (2011). E-Government Adoption Model (GAM): Differing service maturitylevels. Government Information Quarterly, 28(1), 17-35. http://dx.doi.org/10.1016/j.giq.2010.05.006

Snead, J. T., \& Wright, E. (2014). E-government research in the United States. Government Information Quarterly, 31(1), 129-136. http://dx.doi.org/10.1016/j.giq.2013.07.005

Şat, N. (2012). Yerel Yönetimlerde e-devlet uygulamaları. Book section: E-devlet Kamu yonetimi ve Teknoloji İliskisinde Guncel Gelismeler. Editorler: Mehmet Zahid Sobaci, Mete Yildiz, 235-262, Nobel Yayinevi.

Şişman, A., Alkış, Z., \& Maraş, E. E. (2011). E-Devlet ve M-Devlet'in Geliştirilmesinin Önündeki Engel; Sayısal Uçurum. Harita Teknolojileri Elektronik Dergisi, 3(1), 27-37.

Teo, T. S., Srivastava, S. C., \& Jiang, L. (2008). Trust and electronic government success: An empirical study. Journal of Management Information Systems, 25(3), 99-132. http://dx.doi.org/10.2753/mis0742-1222250303

Tung, L. L., \& Rieck, O. (2005). Adoption of electronic government services among business organizations in Singapore. Journal of Strategic Information Systems, 14, 417-440. http://dx.doi.org/10.1016/j.jsis.2005.06.001

Türker, A., \& Türker, Ö. G. (2013). Turistik ürün satın alma davranışının teknoloji kabul modeli ile incelenmesi. Dokuz Eylül Üniversitesi Sosyal Bilimler Enstitüsü Dergisi, 15(2), 281-312.

Venkatesh, V., Morris, M. G., Davis, G. B., \& Davis, F. D. (2003). User acceptance of information technology: Toward a unified view. MIS quarterly, 425-478.

Warkentin, M., Gefen, D., Pavlou, P. A., \& Rose, G. M. (2002). Encouraging citizen adoption of e-government by building trust. Electronic Markets, 12(3), 157-162. http://dx.doi.org/10.1080/101967802320245929

Webster, J., \& Martocchio, J. J. (1993). Turning work into play: Implications for microcomputer software training. Journal of Management, 19(1), 127-146. http://dx.doi.org/10.1177/014920639301900109

West, D. M. (2004). E-Government and the Transformation of Service Delivery and Citizen Attitudes. Public Administration Review, 64(1), 15-27. http://dx.doi.org/10.1111/j.1540-6210.2004.00343.x

Wu, I. L., \& Chen, J. L. (2005). An extension of trust and TAM model with TPB in the initial adoption of on-line tax: An empirical study. International Journal of Human-Computer Studies, 62(6), 784-808. http://dx.doi.org/10.1016/j.ijhcs.2005.03.003

Yıldız, M. (2003). Elektronik (e)-devlet kuram ve uygulamasına genel bir bakış ve değerlendirme. Ed.) Muhittin Acar ve Hüseyin Özgür, Çağdaş Kaти Yönetimi, 1, 314-318.

Yildirim, U., \& Öner, Ş. (2004). Bilgi Toplumu Sürecinde Yerel Yönetimlerde Eğitim-Bilişim Teknolojisinden Yararlanma: Türkiye'de E-Belediye Uygulamalar.. The Turkish Online Journal of Educational TechnologyTOJET, January, 3(1).

Zambak (2012). Yalova Belediyesi ZAMBAK Verileri ve Tanıtım Broşürü, 2012.

\section{Copyrights}

Copyright for this article is retained by the author(s), with first publication rights granted to the journal.

This is an open-access article distributed under the terms and conditions of the Creative Commons Attribution license (http://creativecommons.org/licenses/by/3.0/). 